\title{
Authentication of African green monkey cell lines using human short tandem repeat markers
}

\author{
Jamie L Almeida ${ }^{*}$, Carolyn R Hill ${ }^{2}$ and Kenneth D Cole ${ }^{1}$
}

\begin{abstract}
Background: Tools for authenticating cell lines are critical for quality control in cell-based biological experiments. Currently there are methods to authenticate human cell lines using short tandem repeat (STR) markers based on the technology and procedures successfully used in the forensic community for human identification, but there are no STR based methods for authenticating nonhuman cell lines to date. There is significant homology between the human and vervet monkey genome and we utilized these similarities to design the first multiplex assay based on human STR markers for vervet cell line identification.

Results: The following STR markers were incorporated into the vervet multiplex PCR assay: D17S1304, D5S1467, D19S245, D1S518, D8S1106, D4S2408, D6S1017, and DYS389. The eight markers were successful in uniquely identifying sixty-two vervet monkey DNA samples and confirmed that Vero76 cells and COS-7 cells were derived from Vero and CV-1 cells, respectively. The multiplex assay shows specificity for vervet DNA within the determined allele range for vervet monkeys; however, the primers will also amplify human DNA for each marker resulting in amplicons outside the vervet allele range in several of the loci. The STR markers showed genetic stability in over sixty-nine passages of Vero cells, suggesting low mutation rates in the targeted STR sequences in the Vero cell line.

Conclusions: A functional vervet multiplex assay consisting of eight human STR markers with heterozygosity values ranging from 0.53-0.79 was successful in uniquely identifying sixty-two vervet monkey samples. The probability of a random match using these eight markers between any two vervet samples is approximately 1 in 1.9 million. While authenticating a vervet cell line, the multiplex assay may also be a useful indicator for human cell line contamination since the assay is based on human STR markers.
\end{abstract}

\section{Background}

Misidentification of cell lines has been a continuing problem in academia and industry for decades [1-6]. The most common causes of cell misidentification include mislabeling, contamination of cell lines (i.e. feeder cells used in cocultivation of human stem cells), and xenografting (transplanting living cells, tissues, or organs from one species to another) $[7,8]$. Erroneous data have been published based on results derived from misidentified cells [9] and only recently has an active push for cell authentication been proposed. Nardone et al. attempted to raise awareness of this issue in an open letter to Secretary Michael O. Leavitt at the U.S.

\footnotetext{
* Correspondence: jamie.almeida@nist.gov

${ }^{1}$ National Institute of Standards and Technology, Biochemical Science Division, Bioassay Methods Group, 100 Bureau Drive MS8312, Gaithersburg, MD 20899, USA

Full list of author information is available at the end of the article
}

Department of Health and Human Services [10-12]. Subsequently, NIH has urged researchers to authenticate cell lines in the "Notice Regarding Authentication of Cultured Cell Lines", an addition to their Guidelines for Research [13]. As a result, more scientific journals are now requiring proof of cell line authentication for submission of manuscripts [14]. Major cell repositories are confirming cell line identity by incorporating these data into a large comprehensive international reference database [15]. There are also extensive lists of documented misidentified cells available to educate cell culture users $[3,16]$. In 2009, a working group was formed to develop a standard for authentication of human cells along with a database of short tandem repeat (STR) profiles for human cell lines [14].

Recently, the use of short tandem repeat markers has been recommended for cell line authentication and these methods are currently being used to identify
C Biomed Central

() 2011 Almeida et al; licensee BioMed Central Ltd. This is an Open Access article distributed under the terms of the Creative Commons Attribution License (http://creativecommons.org/licenses/by/2.0), which permits unrestricted use, distribution, and reproduction in any medium, provided the original work is properly cited. 
human cell lines $[17,18]$. The most successful STR markers used in human identification have tetranucleotide repeats for reduced stutter product formation and offer a narrow allele size range that is beneficial for multiplexing [19]. Di- and trinucleotide repeats tend to have higher stutter due to strand slippage during PCR and these markers are generally avoided [20]. Many commercially available kits for human STR profiling target these tetranucleotide repeat regions, give rapid results, and have been well characterized in the forensic community http://www.cstl.nist.gov/biotech/strbase[21]. Additional human STR markers have also been developed for use in complex multiplex assays to aid in human identification and could also be useful in human cell line authentication [22].

Cell authentication targeting STR loci can also be expanded to nonhuman cell lines based on genome availability. This study describes a method to identify cell lines derived from the vervet monkey (C. aethiops sabaeus), commonly known as the African green monkey. Vero cells isolated from the kidney of an African green monkey in 1962 are commonly used for virus amplification, vaccine development, and cytotoxicity assays [23-29]. It has been shown that humans and vervets share homology in their STR regions enabling the use of human STR markers for vervet identification $[30,31]$. The genome for the vervet monkey has not been fully sequenced; however the completed vervet reference sequence is available through The Vervet Functional Genome Project (VFGP). The VFGP is a collaborative effort between researchers at UCLA and McGill University and the Genome Québec Innovation Centre. Data has been published from the collaborative group describing concordance between vervet and known human STR markers [31]. Utilizing known human STR markers and concordant regions found in the vervet reference sequence, we have developed a multiplex assay containing eight human STR markers that successfully genotyped sixty-two vervet genomic DNA samples from monkeys and commonly used vervet cell lines.

\section{Methods}

\section{Selection of loci}

STR markers with high heterozygosity values are beneficial in a multiplex assay as they increase the variability and reduce the chance of a random sample match [19]. This was an important parameter because fifty-nine human STR markers were screened against a panel of vervet monkey DNA samples. Eight STR markers were selected based on the following criteria: 1) heterozygosity values greater than $50 \%, 2$ ) locus must have at least 4 unique alleles, 3) locus must be present in every sample tested, 4) locus must contain a tetranucleotide repeat, and 5) primers for each marker must amplify products in a functional multiplex. Eight human loci (D8S1106, D1S518, D6S1017, D17S1304, D4S2408, D5S1467, D19S245, and DYS389) met the criteria listed above and were incorporated into the vervet multiplex. D17S1304, D5S1467, and D19S245 were identified in the vervet genetic linkage map published by Jasinska et al. [31]. D1S518, D8S1106, and DYS389 were described by Newman et al. in a study utilizing human STR markers for vervet parentage determination [30]. D4S2408 and D6S1017 loci are included in a 26plex assay used for identification of human DNA samples [32]. Chromosomal locations for these markers were found by searching the National Center for Biotechnology Information (NCBI) UniSTS browser [33] for human STR markers. These human chromosomal locations were used to find regions of sequence similarity within the vervet reference sequence supplied by The Vervet Functional Genome Project using the UCSC Genome Browser [34].

\section{Primer design}

Primer3 software http://fokker.wi.mit.edu/primer3/input. htm[35] was used to design PCR primers by inputing the downloaded concordant vervet sequences from the UCSC Genome Browser. The parameters for Primer3 were set to target primers with melting temperatures of $60^{\circ} \mathrm{C}$. AutoDimer software was used to assess primerdimer interactions and hairpin structures within the primers chosen for the vervet multiplex [36]. Forward primers were labeled with one of the following fluorescent dyes at the 5 ' end: 6FAM ${ }^{\mathrm{TM}}$ (blue), VIC ${ }^{\mathrm{TM}}$ (green), $\mathrm{NED}^{\mathrm{TM}}$ (yellow), or PET ${ }^{\mathrm{TM}}$ (red) (Applied Biosystems, Foster, CA). In some cases, an additional guanine base (G) or a "PIGtail" sequence (GTTTCTT) was added to the 5 ' end of the unlabeled reverse primers to promote complete adenylation (Eurofins MWG Operon, Huntsville, AL) [37] (Table 1).

\section{DNA and cell lines}

Sixty vervet monkey genomic DNA samples were obtained from The Nonhuman Primate Research Center Consortium Genome Banks at the University of Washington. These samples originated from the Vervet Research Colony which is part of the Wake Forest University Primate Center and consists of descendants from fifty-seven original founders that were imported from Saint Kitts and Nevis in the mid-1970's. It has been a closed colony since the mid-1980's. Genomic DNA from hamster, rat, gerbil, mouse, pig, baboon, rhesus, and cynomolgus monkey were obtained from Zyagen (San Diego, CA). A total of ten human genomic DNA samples from NIST SRM 2391b (components 1, 3, 4, 5, 7, 8, 9, 10), AmpFeSTR ${ }^{\circledR}$ Control DNA 007 (Applied Biosystems), and a highly characterized human DNA sample 
Table 1 Primers used for STR amplification

\begin{tabular}{|c|c|c|c|}
\hline STR Marker & Forward Primer $\left(5^{\prime}-3^{\prime}\right)$ & Reverse Primer $\left(5^{\prime}-3^{\prime}\right)$ & Primer $\mu \mathrm{M}$ \\
\hline D8S1106 & [FAM]-GTTTACCCCTGCATCACTGG & $\underline{\text { GTCAGAATTGCTCATAGTGCAAGA }}$ & 0.045 \\
\hline DYS389 & [FAM]-CCAACTCTCATCTGTATTATCTATG & 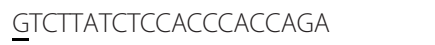 & 0.200 \\
\hline D1S518 & [VIC]-GCAGATCTTGGGACTTCTCG & GTGTGGGCAACTGCATTAGAG & 0.420 \\
\hline D6S1017 & [VIC]-CTGGCACAGGATAGGTGCTC & 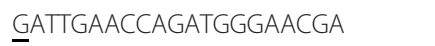 & 0.300 \\
\hline D17S1304 & [NED]-ACCATGTCCTCTGGTTCTGG & GTTTCTIACAGGTGGGACTTGGTGAAA & 0.040 \\
\hline D4S2408 & [NED]-TCATITCCATAGGGTAAGTGAAAA & 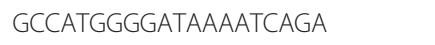 & 0.200 \\
\hline D5S1467 & [PET]-GCCTAAGGTGGTGAATTGGA & 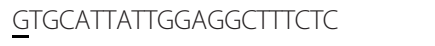 & 0.060 \\
\hline D19S245 & [PET]-GACCTGCAATCAGCCATTTT & $\underline{G} T T C T T G C A G T C T G T G G C T T G$ & 0.360 \\
\hline
\end{tabular}

Reverse primers that did not end in a guanine base at the 5'end were modified by adding an additional guanine (G) base or a "PIGtail" sequence (GTTCTT) to the $5^{\prime}$ end of the reverse primer (underlined) to promote complete adenylation [37]. Primer concentrations listed are final concentrations of forward and reverse primers in a $20 \mu \mathrm{L}$ reaction volume. Primer concentrations were determined empirically based on peak height, DNA concentration, and number of cycles in the PCR program.

of male origin from NIST (N4124) were used for human reference samples. The following cell lines were obtained from The American Type Culture Collection (ATCC, Manassas, VA): Vero (CCL-81), Vero76 (CRL1587), COS-7 (CRL-1651), CV-1 (CCL-70), and HeLa (CCL-2) cells. Vero cells were grown in Minimum Essential Medium (MEM) Alpha (Invitrogen, Carlsbad, CA) with $10 \%$ fetal bovine serum (FBS) (Invitrogen, US origin, qualified), COS-7 and Vero76 cells were grown in Dulbecco's MEM (ATCC) with 10\% FBS, and CV-1 and HeLa cells were grown in Eagle's MEM (ATCC) with $10 \%$ FBS. All cells were grown in a humidified $5 \%$ $\mathrm{CO}_{2}$ balanced-air atmosphere at $37^{\circ} \mathrm{C}$. Vero 76 , COS-7 and $\mathrm{CV}-1$ cells were harvested at passage number 2 using $0.25 \%$ trypsin/0.53 mM EDTA solution (ATCC). Vero cells were harvested over a period of 6 months at passages $7,14,22,35,43,58,63$, and 69 to study changes in the STR profile over high passage number. Trypsin activity was quenched by the addition of an equivalent volume of growth medium and one million cells from each cell line were counted using the Multisizer 3 Coulter Counter (Beckman Coulter, Brea, CA). The Wizard DNA Extraction kit (Promega, Madison, WI) was used to isolate DNA from harvested cells. DNA was quantified using a Nanodrop 1000 (Thermo Scientific, Wilmington, DE) at an absorbance of $260 \mathrm{~nm}$.

\section{PCR amplification}

PCR amplification was performed on a Gene Amp 9700 or Veriti thermal cycler (Applied Biosystems, Foster City, CA). The reaction mixture of $20 \mu \mathrm{L}$ contained 6 ng of vervet DNA, $1 \times$ GeneAmp PCR Gold buffer (Applied Biosystems), $2 \mu \mathrm{M} \mathrm{MgCl} 2$ (Applied Biosystems), $250 \mu \mathrm{M}$ dNTPs (USB Corporation, Cleveland, $\mathrm{OH})$, forward labeled and reverse primers (Table 1), $1 \mathrm{U}$ AmpliTaq Gold DNA Polymerase (Applied Biosystems), and $0.16 \mathrm{mg} / \mathrm{mL}$ BSA (Sigma-Aldrich). PCR conditions for the multiplex assay are as follows: denaturation for $11 \mathrm{~min}$ at $95^{\circ} \mathrm{C}$, amplification for 30 cycles of $45 \mathrm{sec}$ at $94^{\circ} \mathrm{C}, 2 \mathrm{~min}$ at $59^{\circ} \mathrm{C}$, and $1 \mathrm{~min}$ at $72^{\circ} \mathrm{C}$, extension for $60 \mathrm{~min}$ at $60^{\circ} \mathrm{C}$, and a final soak at $25^{\circ} \mathrm{C}$.

\section{PCR product analysis}

Samples were prepared by adding $1 \mu \mathrm{L}$ of amplified product and $0.3 \mu \mathrm{L}$ of GeneScan ${ }^{\mathrm{TM}} 500$ LIZ internal size standard (Applied Biosystems) to $8.7 \mu \mathrm{L}$ of $\mathrm{Hi}-\mathrm{Di}^{\mathrm{TM}}$ (Applied Biosystems) for separation on the 16-capillary ABI 3130xl Genetic Analyzer (Applied Biosystems). A five dye matrix was established under the G5 filter with dyes 6FAM, VIC, NED, PET, and LIZ. POP-4 ${ }^{\mathrm{TM}}$ (Applied Biosystems) was utilized on a $36 \mathrm{~cm}$ capillary array (Applied Biosystems) with 1× ACE buffer (Amresco, Solon, OH). Samples were injected electrokinetically for $10 \mathrm{sec}$ at $3 \mathrm{kV}$. The STR alleles were separated at $15 \mathrm{kV}$ at a run temperature of $60^{\circ} \mathrm{C}$. Data from the $3130 x l$ was analyzed using the GeneMapper $I D-X$ v1.1 Software (Applied Biosystems). Bins and panels were generated in GeneMapper $I D-X$ based on fragment length data from the sixty vervet monkey profiles using fixed bin allele sizes to determine allele calls. Calibration of repeat number to allele fragment length was determined by DNA sequencing.

\section{DNA sequencing}

DNA samples were sequenced to determine the fragment length and number of correlating tetranucleotide repeat units. Sequencing primers were initially designed outside of the multiplex primer region; however, these primers did not always amplify the targeted region efficiently. This may be due to single-nucleotide polymorphisms (SNPs) located in the primer binding sequence or non-specific binding of the primer to other regions of the genome. As a result, the majority of primers used in the multiplex for genotyping were also used for sequencing due to difficulty in finding effective sequencing primers. At least two homozygote samples were sequenced for each STR locus to determine the corresponding number of repeats for each allele. The 
targeted repeat regions were amplified using $0.15 \mu \mathrm{M}$ unlabeled forward and reverse primers (Table 2) using the PCR reaction specified in the PCR Amplification section with the following thermal cycling program: denaturation for $10 \mathrm{~min}$ at $95^{\circ} \mathrm{C}$, amplification for 35 cycles of $1 \mathrm{~min}$ at $94^{\circ} \mathrm{C}, 1 \mathrm{~min}$ at $55-60^{\circ} \mathrm{C}$ (annealing temperature specific to individual primers), and $1 \mathrm{~min}$ at $72^{\circ} \mathrm{C}$, extension for $45 \mathrm{~min}$ at $60^{\circ} \mathrm{C}$, and a final soak at $25^{\circ} \mathrm{C}$. Samples were treated with $2 \mu \mathrm{l}$ of ExoSap-IT ${ }^{\mathrm{TM}}$ (USB Corporation) per $5 \mu \mathrm{l}$ of PCR product to remove unincorporated primers and dNTPs and run on a thermocycler with the following conditions: $90 \mathrm{~min}$ at $37^{\circ} \mathrm{C}$, $20 \mathrm{~min}$ at $80^{\circ} \mathrm{C}$ to inactivate the enzymes, and a final soak at $25^{\circ} \mathrm{C}$. Samples were then sent to Eurofins MWG Operon for sequencing using BigDye ${ }^{\circledR}$ Terminator v3.1 (Applied Biosystems).

\section{Multiplex assay development}

Optimization of the multiplex assay involved identifying an appropriate annealing temperature suitable for all primers included in the assay. Annealing temperature gradients ranging from $55^{\circ} \mathrm{C}$ to $60^{\circ} \mathrm{C}$ were used to screen the multiplex primers for optimal product formation. The concentration of vervet monkey genomic DNA (ranging from $1 \mathrm{ng}$ to $10 \mathrm{ng}$ ) was also optimized based on the primer concentration and program cycle number. We found the most effective parameters for the multiplex to be the following: $59^{\circ} \mathrm{C}$ annealing temperature, $6 \mathrm{ng}$ of vervet DNA, and 30 cycles for the amplification program. The primer concentrations were first optimized individually in monoplex reactions and then were combined into the final multiplex (Table 1).

Table 2 Sequencing primers used for sequence verification and repeat number determination

\begin{tabular}{|c|c|c|c|}
\hline $\begin{array}{l}\text { STR } \\
\text { Marker }\end{array}$ & Sequencing Primers $\left(5^{\prime}-3^{\prime}\right)$ & $\begin{array}{l}\text { Amplicon Size } \\
\text { (bp) }\end{array}$ & $\begin{array}{l}\mathrm{Tm} \\
\left({ }^{\circ} \mathrm{C}\right)\end{array}$ \\
\hline D8S1106 & $\begin{array}{l}\text { F- GTTTACCCCTGCATCACTGG } \\
\text { R- GGTGGCCTAACCAGAGTTGA* }\end{array}$ & $267-291$ & 55 \\
\hline DYS389 & $\begin{array}{l}\text { F - CCAACTCTCATCTGTATTATCTATG } \\
\text { R - GTCTTATCTCCACCCACCAGA }\end{array}$ & $321-337$ & 60 \\
\hline D1S518 & $\begin{array}{l}\text { F - GCAGATCTTGGGACTTCTCG } \\
\text { R - GTGTGGGCAACTGCATTAGAG }\end{array}$ & 182-198 & 55 \\
\hline D6S1017 & $\begin{array}{l}\text { F - CTGGCACAGGATAGGTGCTC } \\
\text { R - GATTGAACCAGATGGGAACGA }\end{array}$ & $354-374$ & 59 \\
\hline D17S1304 & $\begin{array}{l}\text { F - ACCATGTCCTCTGGTTCTGG } \\
\text { R - } \\
\text { GTTTCTTACAGGTGGGACTTGGTGAAA }\end{array}$ & $197-213$ & 60 \\
\hline D4S2408 & $\begin{array}{l}\text { F - TCATTTCCATAGGGTAAGTGAAAA } \\
\text { R - GCCATGGGGATAAAATCAGA }\end{array}$ & $336-360$ & 60 \\
\hline D5S1467 & $\begin{array}{l}\text { F - GCCTAAGGTGGTGAATTGGA } \\
\text { R - GAAGATGGCCCATTTCCATIT* }\end{array}$ & 313-329 & 60 \\
\hline D19S245 & $\begin{array}{l}\text { F - GACCTGCAATCAGCCATTTT } \\
\text { R - GTTCTTGCAGTCTGTGGCTTG }\end{array}$ & $225-249$ & 60 \\
\hline
\end{tabular}

*New primers designed specifically for sequencing purposes. All other primers are original primers developed for the multiplex assay.
Primer concentrations were empirically determined based on peak height balance within the multiplex.

\section{Mixture analysis}

Mixture samples containing genomic DNA extracted from Vero and CV-1 cells and Vero and HeLa cells were analyzed to determine the detection of low levels of contamination in Vero cells using the vervet multiplex assay. DNA from Vero and CV-1 cells were added to individual reactions with a final concentration of $6 \mathrm{ng}$ of DNA in the following ratios 1:1, 2:1, 3:1, 5:1, 7:1, 9:1, and 10:1. Reciprocal reactions were also prepared using DNA from CV-1 and Vero cells. The same procedure was repeated using DNA from Vero and HeLa cells, followed by reciprocal reactions with DNA from HeLa and Vero cells.

\section{DNA analysis}

The heterozygosity $(\mathrm{H})$ values were calculated by dividing the number of heterozygotes at a locus into the total number of individuals. The probability of identity $\left(\mathrm{P}_{\mathrm{I}}\right)$ was calculated by the summation of the square of the genotype frequencies. The probability of a random match (PM) for a full profile was calculated by multiplying the inverse of each genotype frequency for each marker. In the formulas below, $n$ is the number of samples, $P_{i}$ is the frequency of the $i^{\text {th }}$ allele, $x_{i}$ is the frequency of the $i^{t h}$ genotype [19]. A NIST in-house Excelbased statistics program developed by David Duewer was used for these calculations.

$$
\operatorname{Heterozygocity~}(\mathbf{H})=1-\sum_{i}^{n} P_{i}^{2}
$$

$$
\begin{aligned}
& \text { Probability of identity }\left(\mathbf{P}_{\mathbf{I}}\right)=\sum_{i=1}^{n} x_{i}^{2} \\
& \text { Probability of random match }(\mathrm{PM})=\frac{1}{x_{i}} \text { (for a single marker) }
\end{aligned}
$$

\section{Results and Discussion}

\section{STR marker characterization}

The vervet multiplex assay was developed by including eight human STR markers, all comprised of tetranucleotide repeats. The multiplex successfully identified sixty vervet monkey DNA samples received from the Washington National Primate Center resulting in unique profiles for each sample analyzed. Amplified PCR products for all eight loci were observed in every sample. Allele distributions were determined by screening the panel of vervet DNA samples and analyzing fragment lengths. The number of repeats was determined by 
sequencing at least two homozygote samples per locus and correlations were made between the fragment lengths and the number of repeats (Table 3 ).

Four vervet cell lines, Vero, Vero76, CV-1 and COS-7, were also tested using the multiplex assay (Figure 1). Vero and Vero76 genomic DNA samples resulted in identical profiles, confirming that these two cell lines were derived from the same vervet individual [38]. Similarly, DNA extracted from COS-7 cells produced the same profile as the $\mathrm{CV}-1$ cell line from which it was derived [39] (Table 4). Genomic DNA from HeLa cells (female human origin), a common cell culture contaminant, was also analyzed with the multiplex assay which resulted in an "irregular profile". The HeLa alleles were outside of the determined allele range for vervet monkeys in three of the loci (D4S2408, D5S1467, and D19S245) and no amplified product was detected at the DYS389 locus. This was expected because DYS389 is a human marker for the $\mathrm{Y}$ chromosome, found only in males, and HeLa cells are female in origin. In addition to HeLa cell DNA, ten human DNA samples from NIST SRM 2391b (eight components), N4124, and Control DNA 007 were analyzed using the vervet multiplex assay and amplified products were present for all eight loci, excluding DYS389 if the sample was of female origin. In the eleven human samples tested, amplicon sizes for the D19S245 marker ranged from 182 to 202 base pairs, 147 to 176 base pairs for the D5S1467 marker, and 319 to 331 base pairs for the D4S2408 marker (illustrated in Figure 2). These allele ranges correlate with the results found in HeLa DNA.

In vervet monkeys, the DYS389 marker is amplified whether the individual is male or female. This data agrees with a previous study indicating the primers used to amplify the DYS389 marker yield PCR products in both male and female Japanese macaques, suggesting the locus is either autosomal in nature or has sequence homology on the $\mathrm{X}$ and $\mathrm{Y}$ chromosomes [40]. In humans, the primers for DYS389 amplify two products in male samples, DYS389I and DYS389II, and it was found that these products do not exist in Japanese macaques. The data from this study suggests that the same is true for vervet monkeys at this locus. PCR products for the DYS389 marker from Japanese macaques range from 320 to 360 bases, similar to the allele ranges observed in this study for vervets, and in human males they range from 239 to 263 (DYS389I) and 353 to 385 (DYS389II) bases. The differences in the amplified product size for the DYS389 locus can be useful in distinguishing between cell lines of vervet and human (male) origin.

\section{Sequencing repeat regions}

The D4S2408 and D6S1017 loci were based on the human STR markers from a 26plex assay developed to aid in human identification [22]. Since the D4S2408 and the D6S1017 loci are incorporated in both the human 26 plex and the vervet multiplex assays, the samples tested were hypothesized to have the same number of repeats at these loci when the two assays were compared using the same DNA samples; however, this was not the case. When genomic DNA from HeLa cells, Vero cells, and human N4124 was tested with the human 26plex the resulting repeats for the D6S1017 locus were $(8,8),(8,9)$, and $(11,12)$, respectively. When the same DNA was amplified with the vervet multiplex for the D6S1017 locus the resulting repeats were (10, $10),(10,11)$, and $(13,14)$, respectively. The vervet multiplex results have two additional repeats when compared to the 26plex data and this is due to differences found in the nomenclature of the repeat region motif. In the 26plex, the repeat motif is defined as ATCC and the flanking sequence ACCA ACCA does not vary within human DNA sequence at this marker. In vervet DNA, the flanking sequence does vary and is therefore incorporated in the designated repeat motif $[\mathrm{ATCC}]_{\mathrm{n}}[\mathrm{ACCC}]$ ${ }_{n}[\mathrm{ACCA}]_{\mathrm{n}}$. Differences in nomenclature also explain why the human 26plex assay and the vervet multiplex assay give different results at the D4S2408 locus when comparing the same DNA sample. The D4S2408 locus in the 26plex assay has a simple ATCT repeat in human

Table 3 Correlating STR marker fragment length with repeat number

\begin{tabular}{|c|c|c|c|c|}
\hline Human Marker & GenBank & Repeat Region & Allele Distribution (bp) & Number of Repeats \\
\hline D8S1106 & G09378 & {$[A T A G]_{n}$} & $109,121,125,129,133$ & $7,10,11,12,13$ \\
\hline DYS389 & G09600 & {$[C T A T]_{n}$} & $321,325,329,337$ & $10,11,12,14$ \\
\hline D1S518 & G07854 & {$[\mathrm{AGAT}]_{\mathrm{n}}$} & 182, 186, 190, 194, 198 & $13,14,15,16,17$ \\
\hline D6S1017 & G08578 & {$[\mathrm{ATCC}]_{\mathrm{n}}[\mathrm{ACCC}]_{\mathrm{n}}[\mathrm{ACCA}]_{\mathrm{n}}$} & $354,358,362,366,370,374$ & $10,11,12,13,14,15$ \\
\hline D17S1304 & G07960 & {$[\text { TATC }]_{n}$} & 197, 201, 205, 209, 213 & $10,11,12,13,14$ \\
\hline D4S2408 & G08341 & {$[A T C T]_{n}[A C C C][A T C T]_{n}[A C C T]_{n}[A T C T]$} & $336,344,348,352,356,360$ & $13,15,16,17,18,19$ \\
\hline D5S1467 & G08455 & {$[A G A T]_{n}$} & 173, 181, 185, 189 & $8,10,11,12$ \\
\hline D19S245 & L13119 & {$[\mathrm{ATCT}]_{\mathrm{n}}[\mathrm{ATCA}][\mathrm{TCTA}]_{\mathrm{n}}$} & $225,229,233,237,241,245,249$ & $16,17,18,19,20,21,22$ \\
\hline
\end{tabular}

The eight human STR markers incorporated in the multiplex assay with corresponding repeat region, fragment length (based on LIZ GeneScan ${ }^{\mathrm{TM}} 500$ size standard), and number of repeats based on the DNA analysis from sixty-two vervet monkey samples. The correlation of the allele size and number of repeats was determined based on sequencing data. 


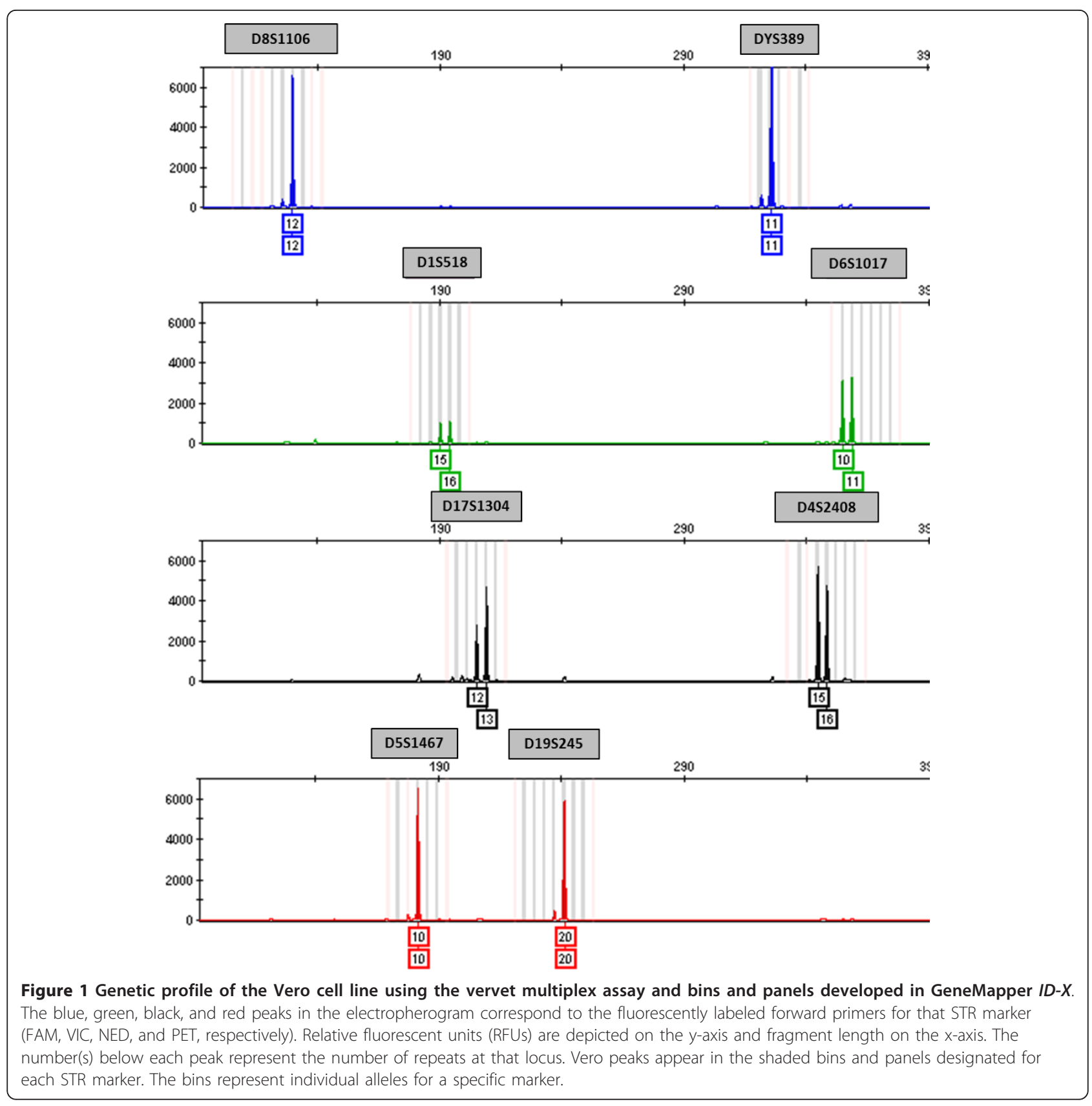

Table 4 Genetic profiles for Vero, Vero76, COS-7, CV-1 cells and two examples of human profiles using the vervet multiplex assay

\begin{tabular}{lcccccccc}
\hline & D8S1106 & DYS389 & D1S518 & D6S1017 & D17S1304 & D4S2408 & D5S1467 & D19S245 \\
\hline Vero/Nero 76 & 12,12 & 11,11 & 15,16 & 10,11 & 12,13 & 15,16 & 10,10 & 20,20 \\
CV-1/COS-7 & 11,13 & 11,11 & 13,16 & 11,12 & 11,11 & 19,19 & 11,11 & 21,21 \\
HeLa & 13,13 & $\mathrm{NA}^{* *}$ & $(188 \mathrm{bp}, 192 \mathrm{bp})^{*}$ & 10,10 & 11,12 & $(327 \mathrm{bp}, 331 \mathrm{bp})^{*}$ & $(147 \mathrm{bp})^{*}$ & $(193 \mathrm{bp}, 197 \mathrm{bp})^{*}$ \\
N4124 & 12,13 & $(251 \mathrm{bp}, 373 \mathrm{bp})^{*}$ & $(192 \mathrm{bp}, 196 \mathrm{bp})^{*}$ & 13,14 & 12,12 & $(322 \mathrm{bp})^{*}$ & $(147 \mathrm{bp}, 176 \mathrm{bp})^{*}$ & $(189 \mathrm{bp}, 193 \mathrm{bp})^{*}$ \\
\hline
\end{tabular}

*Apparent size based on LIZ GeneScan ${ }^{\mathrm{TM}} 500$ size standard. These values do not fall within the vervet allele distribution range or in the designated bins (developed using GeneMapper ID-X Software) for the vervet monkey and therefore are listed as sizes as opposed to repeat numbers.

**No amplified product was detected at this locus because it is of female origin. 


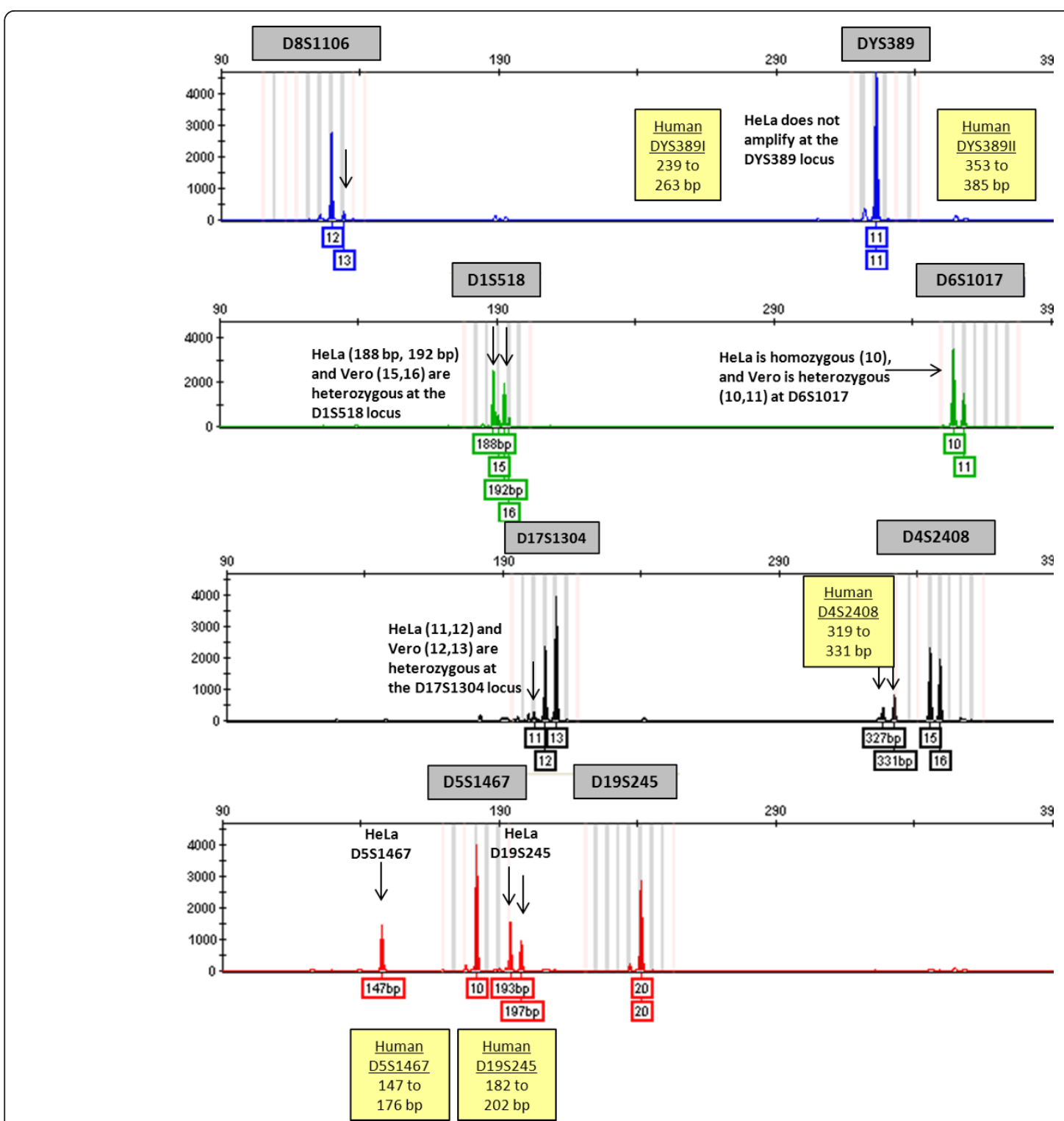

Figure 2 Electropherogram representing a mixture of Vero and HeLa cell DNA (10:1 ratio, respectively). Genetic profiles were analysed using bins and panels developed in GeneMapper ID-X. Relative fluorescent units (RFUs) are depicted on the $y$-axis and fragment length on the $x$-axis in the electropherogram. Arrows depict HeLa alleles which may or may not appear in the bins and panels designated for Vero samples. Vero alleles appear in the shaded bins and panels designated for each STR marker. The number(s) below each peak represent the number of repeats at that locus. At the D4S2408, D5S4167, and D19S245 markers, HeLa DNA amplifies outside the observed vervet allele range and those values are represented as fragment lengths (bp) instead of repeat numbers. HeLa cells do not amplify at the DYS389 locus because they are of female origin. Human allele ranges that differ from vervet monkeys are illustrated in yellow boxes.

sequence; however, in vervet sequence we observed a more complex repeat of $[\mathrm{ATCT}]_{\mathrm{n}}[\mathrm{ACCC}][\mathrm{ATCT}]_{\mathrm{n}}$ $[\mathrm{ACCT}]_{\mathrm{n}}[\mathrm{ATCT}]$. The flanking regions outside the repeat region are identical in both human and vervet sequence. Due to differences in length of the D4S2408 repeat region found in human and vervet DNA, human samples result in smaller fragment lengths of the repeat amplicon when compared to the vervet allele range in the multiplex assay.

\section{Evaluation of STR markers}

High heterozygosity values are important in selecting STR markers for human identification purposes [41]. In general, markers with high heterozygosity values give a greater chance of discriminating between any two individuals. Observed heterozygosity values greater than $70 \%$ were used in the selection process for STR markers for human identification applications [19]. Observed heterozygosity values were measured for each of the markers 
in the vervet multiplex based on sixty-two vervet genomic DNA samples (Table 5). The two loci that resulted in the highest observed heterozygosity values are D19S245 (0.790) and D1S518 (0.710). The STR markers with the lowest observed heterozygosity values (0.532) were DYS389 and D4S2408. The D1S518 locus gave comparable results to those published by Newman et al. [30]. These researchers used a smaller sample size of fifty-five monkeys, and found five alleles associated with this locus with an observed heterozygosity value of 0.596 . The heterozygosity value for D1S518 calculated in this study is higher (0.710) than the value calculated in the Newman paper and is likely due to the number and type of samples analyzed in each study. The probability of identity $\left(\mathrm{P}_{\mathrm{I}}\right)$ was calculated for each marker (Table 5). For example, the D8S1106 marker has a probability of 1 in 9 that any two vervet samples would match at this marker. Since the eight markers are all located on separate chromosomes, we can multiply the probability of identity for each marker to determine a random match. The probability of a random match using eight STR markers between any two vervet samples is 1 in 1.9 million.

\section{Species specificity of the assay and profile stability}

To determine the specificity of the selected STR markers, genomic DNA from pig, mouse, hamster, rat, gerbil, baboon, rhesus, and cynomolgus monkey were tested using the vervet multiplex assay. DNA samples with concentrations ranging from $2 \mathrm{ng}$ to $100 \mathrm{ng}$ were added to individual reactions and samples were amplified according to the methods in the PCR amplification section. All eight non-vervet DNA samples resulted in incomplete or irregular profiles in the limited number of samples tested based on the bins and panels developed for the vervet monkey in GeneMapper $I D-X$ (data not shown). To further explore the genetic diversity between these species would require screening of additional samples; however, this is beyond the scope of the study.

Table 5 Observed heterozygosity and probability of identity values calculated for STR markers in the vervet multiplex samples

\begin{tabular}{cccc}
\hline STR Marker & Number of Alleles & $\begin{array}{c}\mathbf{H} \\
\text { (obs) }\end{array}$ & $\begin{array}{c}\mathbf{P}_{\mathbf{1}} \\
\text { (obs) }\end{array}$ \\
\hline D8S1106 & 5 & 0.645 & 0.111 \\
DYS389 & 4 & 0.532 & 0.226 \\
D1S518 & 5 & 0.710 & 0.143 \\
D6S1017 & 6 & 0.629 & 0.222 \\
D17S1304 & 5 & 0.677 & 0.110 \\
D4S2408 & 6 & 0.532 & 0.282 \\
D5S1467 & 4 & 0.581 & 0.264 \\
D19S245 & 7 & 0.790 & 0.082 \\
\hline
\end{tabular}

Heterozygosity $(H)$ and probability of identity $\left(P_{1}\right)$ values were calculated for each STR marker using data from sixty-two vervet monkeys.
A multiplex assay that can detect contamination of other cell lines within a mixed sample would be useful. Contamination of Vero cells with another vervet cell line $(\mathrm{CV}-1)$ or a human cell line (HeLa) was analyzed using simulated mixture samples. Mixture ratios ranging from 1:1 to $10: 1$ consistently showed mixed profiles using the multiplex assay. Even at the highest dilution in Vero DNA (5.45 ng), low concentrations of HeLa and CV-1 DNA (0.55 ng) were detected within a Vero profile (See Figure 2). The inverse is also true. Samples containing low levels of Vero DNA (0.55 ng) produced a full Vero profile even with high levels of CV-1 DNA present and resulted in a partial profile with high levels of HeLa DNA. The partial profile consisted of six STR markers, D8S1106, DYS389, D1S518, D17S1304, D5S1467, and D19S245, and the remaining two loci, D4S2408 and D6S1017, resulted in peaks that were below the analytical threshold of 50 relative fluorescent units (RFU).

Genetic stability of the eight STR markers was evaluated over high cell passage number to ensure a stable profile will be generated as the cell line ages. DNA extracted from Vero cells harvested at passage numbers $7,14,22,35,43,58,63$, and 69 were analyzed using the multiplex assay. After samples were amplified and separated based on fragment length, it was determined that there was complete concordance in the Vero profile up to 69 passages. These data suggest that the STR loci are stable with low mutation rates in the Vero cell line.

\section{Conclusions}

A multiplex assay based on eight human STR markers with observed heterozygosity values ranging from 0.532 to 0.790 was developed, and the probability of a random match using these markers between any two vervet samples is approximately 1 in 1.9 million. There are several advantages of using an STR assay to genotype vervet cells and their derivatives including the ability to obtain more information from a multiplex, the rapid detection using PCR and capillary electrophoresis separation, and the relative low cost of materials and reagents.

The markers described in this assay can be useful to authenticate cell lines derived from individual vervet monkeys; however, vervet cells derived from the same individual will result in identical profiles. Additional specific assays are required to distinguish between cell lines derived from the same origin. For example, COS-7 and CV-1 cells result in the same genetic STR profile, so a test for SV40 T antigen could be used to differentiate COS-7 cells from CV-1 cells [39].

Genetic stability of the eight loci in this assay was shown to be consistent at high passage in the Vero cell line over a period of six months. This supports the findings of Chiong et al. where they concluded STR 
profiling of human bladder cancer cell lines does not change with passage number [42]. Parson et al. described genetic stability in some human leukemia cell lines and instability in others after passaging cells for one year and analyzing the DNA fingerprints using STR markers [43]. High cell passage number has been shown to increase the risk of alterations in DNA fingerprinting and best practices suggest cell identification at low passage numbers [44].

In addition to authenticating vervet cell lines, this assay may be a useful indicator for human cell line contamination since the assay is based on human STR markers. Human DNA amplifies at each marker; however, the fragment sizes are outside the observed vervet allele range at the following loci: D4S2408, D5S1467, D19S245, and DYS389. Human cell line contamination can be confirmed using validated STR markers [17]. The vervet multiplex assay was unable to generate complete profiles in the observed vervet allele range for more distantly related species, and we are currently developing additional markers to target several of these in an allinclusive multiplex assay.

\section{Acknowledgements}

The authors express appreciation for the expert advice and direction of Michael Coble, Margaret Kline, Peter Vallone, Erica Butts, and John Butler (NIST, Applied Genetics Group).

Official Disclaimer: Certain commercial equipment, instruments, or materials are identified in this paper to specify the experimental procedure adequately. Such identification is not intended to imply recommendation or endorsement by the National Institute of Standards and Technology, nor is it intended to imply that the materials or equipment identified are necessarily the best available for the purpose.

\section{Author details}

${ }^{1}$ National Institute of Standards and Technology, Biochemical Science Division, Bioassay Methods Group, 100 Bureau Drive MS8312, Gaithersburg, MD 20899, USA. ${ }^{2}$ National Institute of Standards and Technology, Biochemical Science Division, Applied Genetics Group, 100 Bureau Drive MS8316, Gaithersburg, MD 20899, USA.

\section{Authors' contributions}

JA carried out the cell work, PCR optimization, capillary electrophoresis, GeneMapper ID-X software analysis, and sample preparation for and analysis of the sequencing results. KC participated in the design and coordination of the study. $\mathrm{CH}$ participated in the multiplex optimization parameters. JA drafted the manuscript and $\mathrm{CH}$ and $\mathrm{KC}$ revised it critically for important intellectual content. All authors read and approved the final manuscript.

Received: 18 July 2011 Accepted: 7 November 2011

Published: 7 November 2011

\section{References}

1. Gartler S: Apparent HeLa cell contamination of human heteroploid cell lines. Nature 1968, 217(5130):750-751.

2. Nelson-Rees W, Daniels D, Flandermeyer R: Cross-contamination of cells in culture. Science 1981, 212(4493):446-452.

3. Capes-Davis A, Theodosopoulos G, Atkin I, Drexler H, Kohara A, MacLeod R, Masters J, Nakamura Y, Reid Y, Reddel R, et al: Check your cultures! A list of cross-contaminated or misidentified cell lines. Int J Cancer 2010, 127:1-8.

4. Miller L: Identity crisis. Nature 2009, 457(7232):935-936.
5. Chatterjee R: Cell biology. Cases of mistaken identity. Science 2007, 315:928-931.

6. Lucey B, Nelson-Rees W, Hutchins G: Henrietta Lacks, HeLa cells, and cell culture contamination. Arch Pathol Lab Med 2009, 133:1463-1467.

7. Nims R, Sykes G, Cottrill K, Ikonomi P, Elmore E: Short tandem repeat profiling: part of an overall strategy for reducing the frequency of cell misidentification. In Vitro Cell Dev Biol 2010, 26:811-819.

8. Pathak S, Nemeth M, Multani A: Human tumor xenografts in nude mice are not always of human origin: a warning signal. Cancer 1999, 86:898-900.

9. Stacey G: Cell contamination leads to inaccurate data: we must take action now. Nature 2000, 403(6768):356.

10. Nardone R: Curbing rampant cross-contamination and misidentification of cell lines. Biotechniques 2008, 45(3):221-227.

11. Nardone R: An open letter regarding the misidentification and crosscontamination of cell lines: significance and recommendations for correction.Edited by: Leavitt SMO 2007.

12. Buehring G, Eby E, Eby M: Cell line cross-contamination: how aware are mammalian cell culturists of the problem and how to monitor it? In Vitro Cell Dev Biol Anim 2004, 40(7):211-215.

13. National Institutes of Health: Notice regarding authentication of cultured cell lines. Nov. 28, 2007.[http://grants.nih.gov/grants/guide/notice-files/ NOT-OD-08-017.html].

14. Barallon R, Bauer S, Buter J, Capes-Davis A, Dirks W, Elmore E, Furtado M, Kline $M$, Kohara A, Los $G$, et al: Recommendation of short tandem repeat profiling for authenticating human cell lines, stem cells, and tissues. In Vitro Cell Dev Biol 2010, 46:727-732.

15. Dirks W, Drexler $\mathrm{H}$ : Online verification of human cell line identity by STR DNA typing. Methods Mol Biol 2011, 731:45-55.

16. ATCC SDO Workgroup ASN-0002: Cell line misidentification: the beginning of the end. Nat Rev Cancer 2010, 10(6):441-448.

17. Masters J: Short tandem repeat profiling provides an international reference standard for human cell lines. Proc Natl Acad Sci USA 2001, 98:8012-8017.

18. Lorenzi P, Reinhold W, Varma S, Hutchinson A, Pommier Y, Chanock S, Weinstein J: DNA fingerprinting of the NCl-60 cell line panel. Mol Cancer Ther 2009, 8(4):713-724.

19. Butler J: Forensic DNA typing: biology, technology, and genetics of STR markers, 2nd edn. London: Elsevier Academic Press; 2005.

20. Walsh P, Fildes N, Reynolds R: Sequence analysis and characterization of stutter products at the tetranucleotide repeat locus vWA. Nucleic Acids Res 1996, 24(14):2807-2812.

21. Ruitberg C, Reeder D, Butler J: STRBase: a short tandem repeat DNA database for the human identity testing community. Nucleic Acids Res 2001, 29(1):320-322.

22. Hill C, Butler J, Vallone P: A 26plex autosomal STR assay to aid human identity testing. J Forensic Sci 2009, 54(5):1008-1015.

23. Montagnon B, Fanget B, Nicolas A: The large-scale cultivation of vero cells in micro-carrier culture for virus vaccine production - preliminary results for killed poliovirus vaccine. Developments in Biological Standardization 1981, 47:55-61.

24. Vincent-Falquet J, Peyron L, Souvras M, Moulin J, Tektoff J, Patet J: Qualification of working cell banks for the vero cell line to produce licensed human vaccines. Developments in Biological Standardization 1989, 70(1):53-56

25. Montagnon B: Polio and rabies vaccines produced in continuous cell lines: A reality for vero cell line. Dev Biol Stand 1989, 70:27-47.

26. Barrett $P$, Berezuk $G$, Fritsch $S$, Aichinger $G$, Hart M, El-Amin W, Kistner $\mathrm{O}$, Ehrlich $\mathrm{H}$ : Efficacy, safety, and immunogenicity of a vero-cell-culturederived trivalent influenza vaccine: a multicentre, double-blind, randomised, placebo-controlled trial. Lancet 2011, 377(9767):751-759.

27. Govorkova E, Kaverin N, Gubareva L, Meignier B, Webster R: Replication of influenza A viruses in a green monkey kidney continuous cell line (vero). The Journal of Infectious Diseases 1995, 172(1):250-253.

28. Halter M, Almeida J, Tona A, Elliott J, Plant A, Cole K: A mechanistically relevant cytotoxicity assay based on the detection of cellular green fluorescent protein. ASSAY and Drug Development Technologies 2009, 7(4):356-365.

29. Valdivieso-Garcis A, Clarke R, Rahn K, Durette A, MacLeod D, Gyles C: Neutral red assay for measurement of quantitative vero cell cytotoxicity. Applied and Environmental Microbiology 1993, 59(6):1981-1983. 
30. Newman T, Fairbanks L, Pollack D, Rogers J: Effectiveness of human microsatellite loci for assessing paternity in a captive colony of vervets (Chlorocebus aethiops sabaeus). Am J Primatol 2002, 56(4):237-243.

31. Jasinska A, Service S, Levinson M, Slaten E, Lee O, Sobel E, Fairbanks L, Bailey J, Jorgensen $\mathrm{M}$, Breidenthal $\mathrm{S}$, et al: A genetic linkage map of the vervet monkey (Chlorocebus aethiops sabaeus). Mamm Genome 2007, 18:347-360.

32. Hill C, Kline M, Coble M, Butler J: Characterization of 26 miniSTR loci for improved analysis of degraded DNA samples. J Forensic Sci 2008, 53(1):73-80.

33. National Center for Biotechnology Information (NCBI) UniSTS Browser. [http://www.ncbi.nlm.nih.gov/unists].

34. Vervet UCSC Genome Browser. [http://genomequebec.mcgill.ca/compgen/ submit_db/vervet_project/vervet_vs_human_hg19].

35. Rozen $S$, Skaletsky $H$, (eds.): Primer3 on the WWW for general users and for biologist programmers. Totowa, NJ: Humana Press; 1999.

36. Vallone P, Butler J: AutoDimer: a screening tool for primer-dimer and hairpin structures. Biotechniques 2004, 37(2):226-231.

37. Brownstein M, Carpten J, Smith J: Modulation of non-templated nucleotide addition by Taq DNA polymerase: primer modifications that facilitate genotyping. BioTechniques 1996, 20(6):1104-1010.

38. Earley $\mathrm{E}$, Johnson $\mathrm{K}$ : The lineage of the Vero, Vero76, and its clone C1008 in the United States. In VERO CELLS-origin, properties and biomedical applications. Edited by: Terasima BSaT. Chiba; 1988:26-29.

39. Gluzman Y: SV40-transformed simian cells support the replication of early SV40 mutants. Cell 1981, 23(1):175-182.

40. Ago K, Ago M, Nakagawa S, Ogata M: Highly polymorphic STR marker amplified with human DYS389 primers in Japanese macaques (Macaca fuscata). American Journal of Primatology 2006, 68:1025-1031.

41. Coble M, Butler J: Characterization of new miniSTR loci to aid analysis of degraded DNA. J Forensic Sci 2005, 50(1):43-53.

42. Chiong E, Dadbin A, Harris L, Sabichi A, Grossman H: The use of short tandem repeat profiling to characterize human bladder cancer cell lines. J Urol 2009, 181(6):2737-2748.

43. Parson W, Kirchebner R, Muhlmann R, Renner K, Kofler A, Schmidt S, Kofler $R$ : Cancer cell line identification by short tandem repeat profiling: power and limitations. FASEB Journal 2005, 19(3):434-436.

44. Reid Y: Characterization and authentication of cancer cell lines: an overview. Methods Mol Biol 2011, 731:35-43.

doi:10.1186/1472-6750-11-102

Cite this article as: Almeida et al: Authentication of African green monkey cell lines using human short tandem repeat markers. BMC Biotechnology 2011 11:102.

\section{Submit your next manuscript to BioMed Central and take full advantage of:}

- Convenient online submission

- Thorough peer review

- No space constraints or color figure charges

- Immediate publication on acceptance

- Inclusion in PubMed, CAS, Scopus and Google Scholar

- Research which is freely available for redistribution 